\title{
Para-organic intensification of future farming as alternative concept to reactor-based staple food production in Africa
}

\author{
Daniel Neuhoff - Julius Kwesiga
}

Received: 8 May 2020 / Accepted: 16 September 2020 / Published online: 15 January 2021

(C) The Author(s) 2021

\begin{abstract}
Currently, staple food self-sufficiency in Africa is just above $80 \%$, and the population is expected to more than double until 2050. To cope with this challenge, technological solutions such as reactor food seem seductive. Western pilot projects have shown considerable production potentials, e.g., $7 \mathrm{t} \mathrm{ha}^{-1}$ of starch within 150 days by algae in reactors that may also be used in Africa. Are these approaches suitable for Africa justifying extensive research activities? Here, we argue that both physical availability of substrates and missing profitability substantially limit the development of reactor food in SSA, also in a mid-term perspective. It is rather suggested to close the considerable existing yield gaps by implementing para-organic farming systems, which combine basic principles of organic farming such as crop diversification, legume growing, and manuring, with a reasonable use of inputs, in particular mineral fertilizers. In combination with irrigation, staple food production in SSA has the potential to keep pace with growing demand.
\end{abstract}

Keywords Agricultural productivity - Soil fertility . Ecological intensification · Sub-Saharan Africa

D. Neuhoff $(\bowtie) \cdot$ J. Kwesiga

Institute of Crop Science and Resource Conservation, Dpt. of Agro-Ecology and Organic Farming, University of Bonn, Auf dem Hügel 6, 53121 Bonn, Germany

e-mail: d.neuhoff@uni-bonn.de

\section{Introduction}

The biophysical conditions for food production by smallholder farmers in Africa are ambivalent. Low inherent soil fertility including phosphate $(\mathrm{P})$ deficiency generally reduce crop productivity (Sanchez 2002), while climatic conditions, in particular solar radiation and temperature, strongly favor crop growth, if nutrients and water are not limiting. A major reason for the low productivity of African agriculture is poor nutrient management, often resulting from missing know-how and capital (Tittonell and Giller 2013). Current low food security in sub-Saharan Africa (SSA) may increasingly be jeopardized by climate change and a growing African population.

Some people argue that so-called reactor food is a promising option to satisfy the future food demand of SSA. Accordingly, landless food production can be used to compensate for land loss, to recycle nutrients from waste streams and to integrate urban areas into farming systems. It is even postulated that the high spatial efficiency of photobioreactors, with regard to protein, carbohydrate, and oil production, could be used to free cropland for more sustainable production (Rahmann et al. 2019). Here, we critically question this approach based on an analysis of substrate availability for food reactors. Contrastingly, a para-organic approach is proposed, which integrates classical organic management practices and reasonable use of chemical inputs, to increase food production in SSA. The paper highlights key elements of this approach focusing on agronomic aspects. 


\section{Limits of the approach of reactor-based staple food production}

In contrast to land-based food, reactor food is the outcome of biochemical processes carried out in controlled artificial environments. During the process, any type of biomass may be converted into nutrients, physiologically available for humans, such as carbohydrates, fats, and proteins. For example, wheat straw in theory can be converted to sugars physiologically available for humans. More sophisticated, meat could be produced with muscle cells reproduced on nutrient solutions (Orzechowski 2015; Bhat et al. 2015). Both processes have in common that they need substrates for metabolism unless using photoautotrophic bioreactors.

Basically, all types of biomass such as crop residues, organic household waste, slurry, grass, wood, algae, or even sewage sludge could fuel the reactors provided that efficient techniques for conversion and hygienization are available (Rahmann et al. 2019). For any practical application in SSA, the physical availability of residuefree substrates in sufficient amounts is indispensable. Sustainably running food reactors also depends on economic competitiveness.

Hitherto, the reactor food approach is without any relevance for current world nutrition. Potentials and constraints however need to be assessed before setting any future research agenda, taking socio-economic, technical, and ecological implications into account. Here, we focus on economic and biophysical constraints, not taking into account expected social and cultural implications of reactor food.

First and foremost, reactor food will meet serious economic constraints, mainly due to the low purchasing power of the people in sub-Saharan Africa (SSA), unless economies will make a quantum leap in this century. Missing capital is currently already one of the main reasons for the low productivity of smallholder farming in Africa. When assuming no financial constraints, both the physical availability of substrates for the reactor and the access to reactor food in needy areas still remain the key challenges.

Constraints to substrate availability mainly occur in regions where plant biomass production is low, e.g., the Sahel zone. Low rainfall and poor soils in these regions not only limit current food supply but also potential reactor substrate supply. Problems in these regions are exacerbated by poor infrastructure and missing capital. In regions with favorable agronomic conditions, in contrast, exploiting the potential of land-based food production systems, i.e., closing yield gaps, needs to be prioritized for economic reasons. However, some types of biomass, e.g., algae, could be a promising substrate for bioreactors in coastal regions.

It is also important to consider ecological aspects of substrate provision and alternative use options for biomass. Crop residues and animal manure, for example, are essential components to maintain soil fertility (Mäder et al. 2002). Wooden biomass can be used for various other purposes such as construction, commodities, and fire wood. To avoid competition with alternative substrate use, the implementation of photoautotroph systems seems most promising, if economic and technical constraints can be resolved. Experiments with photoautotrophic microalgae have shown that a total of $7 \mathrm{t} \mathrm{ha}^{-1}$ of starch could be produced within 150 days even under the climatic conditions of Central Europe (Brányiková et al. 2011). This is a highly productive process, however, only equaling some $50 \mathrm{t} \mathrm{ha}^{-1}$ of potato yield with $20 \%$ dry matter (DM) and $70 \%$ starch in the DM. Upscaling the photoautotrophic process of starch production via microalgae would require large areas of land that could be used for presumably more competitive arable cropping as well. In addition, all resources needed for algae growth would have to be supplied externally including mineral elements such as P. Outsourcing algae starch production to unfertile regions, in theory the best option, would provoke unsolvable logistical and infrastructural problems.

The main challenges for reactor food, however, remain the technical feasibility and the affordability of reactor food for low-income countries in SSA. Given the fact that SSA economies generally have a low technological standard, sophisticated approaches requiring special know-how and capital do not seem suitable.

To feed Africa sustainably, increased crop productivity and production are of primary importance. Implementing key elements of Organic Farming in African cropping systems could help to improve current productivity, if they are embedded in a free concept of ecological intensification. According to Tittonell and Giller (2013) "ecological intensification is now understood as a means of increasing agricultural outputs (food, fibre, agro-fuels and environmental services) while reducing the use and the need for external inputs (agrochemicals, fuel, and plastic), capitalising on ecological processes that support and regulate primary productivity in agro-ecosystems". Here, we suggest a 
para-organic approach for smallholder farmers in Africa to describe those systems. Based on the principles of organic agriculture, para-organic farming considers the specific situation in low-income countries. The relative importance of affordable healthy food and fair farmer incomes is higher than ecological aspects, such as resource efficiency, strict input restrictions, or certification-unless serving organic markets. Siteadapted new varieties, robust to abiotic and biotic stress, even if derived from new breeding techniques such as CRISPR-CAS, could be used in those systems (Table 1). A sporadic use of pesticides is not categorically excluded. Similar to organic farming, proactive soil fertility management is a precondition for successfully running these systems.

\section{Improving soil fertility and crop management}

In the frame of a recent research project, we carried out extensive studies on paddy rice and maize productivity from 2015 to 2018 on two sites in East Africa (https://www.wetlands-africa.uni-bonn.de/). The experiments, which were in part conducted on wetland soils during the dry season, revealed both a considerable maize production potential during the dry season and yield gaps in Uganda. Intensive mineral nitrogen application $\left(120 \mathrm{~kg} \mathrm{~N} \mathrm{ha}^{-1}\right)$ resulted on average of three seasons in maize grain yields of $5 \mathrm{tha}^{-1}$, while only $1.6 \mathrm{t} \mathrm{ha}^{-1}$ under farmer's practice. High application rates of organic amendments (poultry and green manure equaling $120 \mathrm{~kg} \mathrm{~N} \mathrm{ha}^{-1}$ ) gave yields of $4.2 \mathrm{t} \mathrm{ha}^{-1}$ (Alibu et al. 2019). Significant yield increases were also recorded in our trials with paddy rice in the Kilombero flood plain in Tanzania after mineral nitrogen application (Kwesiga et al. 2019). In the same experiments, rice grain yields have been doubled compared with farmers practice $\left(3 \mathrm{t} \mathrm{ha}^{-1}\right)$, just by implementing good agricultural practices combined with a reasonable urea input of $60 \mathrm{~kg} \mathrm{~N} \mathrm{ha}^{-1}$ (Kwesiga et al. 2019). Yield-increasing effects in these experiments were also recorded when repeatedly applying animal and green manure. Farm yard manure application $\left(60 \mathrm{~kg} \mathrm{~N} \mathrm{ha}^{-1}\right)$ combined with green manure resulted in positive nitrogen balances (Kwesiga et al. 2020). Avoiding soil mining by keeping nitrogen balances in equilibrium is also essential to maintain long-term crop productivity (Tittonell et al. 2006). Regularly adding organic amendments is consequently a key component to maintain soil fertility. Longterm experiments in West Africa have shown that

Table 1 Contrasting and common elements of organic and para-organic farming

\begin{tabular}{ll}
\hline Organic & Para-organic \\
\hline Sophisticated farm management & Simple technologies \\
High respect toward non-human life & Stronger focus on human needs \\
High product and process quality & Cheap standard quality products \\
No use of synthetic mineral fertilizers & Reasonable use of mineral NPK-fertilizers \\
Restricted list of approved natural insecticides e.g. & Facultative use of synthetized natural insecticides or even synthetic \\
$\quad$ botanicals and fungicides & insecticides in emergency cases \\
Exclusive use of classical breeding technologies & Open-minded towards new breeding techniques such as CRISPR-CAS \\
Inclusion of the consumers & No specific consumer profile \\
Premium prices on local and global organic markets & Normal prices on local and regional markets \\
Certification & No certification \\
Common elements & \\
Priority to organic soil fertility management & \\
Regular manuring of soils & \\
Including legumes in crop rotations & \\
Diversification of crop production & \\
Biological pest control & \\
No use of herbicides & \\
Animal-friendly husbandry & \\
\hline
\end{tabular}


repeated application of compost can help to stabilize maize yields on higher levels even if high amounts of mineral nitrogen were applied (Guibert 1999) indicating organo-mineral fertilization to be the best "para-organic" fertility management option.

However, there are several constraints for implementing para-organic management strategies for soil fertility in SSA. First and foremost, animal manure is rare, and production requires mixed farming systems including stable systems. Both do currently not exist in many regions and would require a significant social shift targeted on making pastoralists farmers and vice versa. Compost is hardly available, except low amounts of vermicompost, e.g., in Ethiopia. Green manure application, another promising approach to increase soil fertility, is hardly adopted by farmers, although knowledge has been available for decades (e.g., http://www. tropicalforages.info/). In addition, legume productivity may be limited by P supply, a mineral not infrequently deficient in tropical soils (Sanchez 2002).

Interestingly, a recently published yield comparison between conventional and organic systems in the Kenyan highlands showed comparable corn yields (appr. $5 \mathrm{t} \mathrm{ha}^{-1}$ ) for both systems (Adamtey et al. 2016). The total annual $\mathrm{N}$ input over two seasons and crops (corn and cabbage) amounted $251 \mathrm{~kg} \mathrm{~N} \mathrm{ha}^{-1}$ in both systems. Organic inputs were based on composted farm yard manure and both Tithonia mulch and tea taken from hedges and wild collection. Such an approach is feasible for individual organic farms but not on a larger scale, due to limited resource availability. Given the low current input level of mineral fertilizers, in particular $\mathrm{N}$ and $\mathrm{P}$, and the low availability of green manure seeds, approaches for ecological intensification in SSA need to consider both, a reasonable amount of mineral fertilizer input and the siteadapted use of available organic amendments.

For a proper analysis of the agricultural conditions in SSA, it is particularly important to give a fair assessment on mineral nitrogen fertilizers. The negative implications of its use, in particular substantial fossil energy consumption, release of reactive nitrogen into the atmosphere, eutrophication, and potential food quality impairment, have to be counterbalanced with the evident yield increasing effect. For African agriculture, the strict non-use of mineral nitrogen fertilizers, a compulsory rule in Organic Farming, is not a viable option, unless for local or global organic niche production. The historical argumentation that the use of nitrogen fertilizers is the starting point of a general intensification including also other chemicals, e.g., for crop protection, is not necessarily true for SSA. However, the use of mineral nitrogen fertilizers should be limited as much as possible for reasons of resource conservation and protection. To ensure a sustainable global development, in a medium term, it will be decisive to fuel global mineral $\mathrm{N}$ fertilizer production with renewable energy sources (Shipman and Symes 2017).

Furthermore, a diversification of cropping systems with respect to staple food may be needed. In the Arsi region in Ethiopia, for example, close to $80 \%$ of the arable land is exclusively used for wheat production, making these systems prone to calamities such as black rust (Puccinia graminis). Under these conditions, crop diversification and the use of animal and green manure including legumes, all key elements of both, organic and para-organic farming, could help to stabilize the systems, if economically viable. Currently, the key constraint for crop diversification of smallholder farms in Africa is the lower short-term income generation. Comparable with western agriculture, growers focus on profitable crops, making farmers in the Arsi region mainly grow wheat. The logic of the market mechanisms can only be interrupted with a change in the consuming behavior, targeted also on diet diversification.

Based on the suggested para-organic approach for soil fertility management, other innovations can help to further increase crop productivity and production in Africa.

\section{Water harvesting and irrigation}

According to the global report published by IAASTD (2009), rain water harvesting and irrigation have a great potential to increase crop productivity in African regions with sufficient total rainfall, but unfavorable rainfall patterns. Including a second growing season could help to significantly increase crop production. A recent study in the savannah region of Northern Togo, for example, showed a considerable production potential of maize during the dry season (Gadédjisso-Tossou et al. 2020). Rain fed production can also be upgraded with supplemental irrigation to increase yield stability by avoiding temporary drought stress. According to Burney et al. (2013) "investments in distributed smallholder irrigation technologies might be used to (i) use the water sources of SSA more productively, (ii) improve nutritional outcomes and rural development throughout SSA, and (iii) narrow the income disparities that permit widespread 
hunger to persist despite aggregate economic advancement." However, similar to other economic activities, SSA is lagging behind compared with other regions such as South East Asia. In reality, irrigation in SSA only plays a minor role mainly due to missing capital for investing in pumping systems (Burney et al. 2013). Many irrigations schemes in Africa perform poorly and fail to lift farmers out of poverty and to increase food security (Bjornlund et al. 2017). Important factors for successful performance include management style, irrigation method, crop mix, and type of funding (Mutiro and Lautze 2015).

Establishing irrigation facilities still remains the paradigm for ecological intensification if based on sustainable water harvesting. Missing technical skills and capital, however, currently limit the adoption of this approach in SSA. Similar to other innovations, the profitability of this approach might be critical since it mainly depends on yield response and producer prices. Public funding will be needed. Higher prices, probably resulting from increasing global food demand, may additionally help to boost investment in irrigation also in low-income countries. Social and economic factors such as profitability, risk implications, and input and output changes, including weather variability, will influence the adoption probability of any introduced technology (Kassie et al. 2015).

\section{Reducing post-harvest losses}

According to the African Postharvest Losses Information System (https://www.aphlis.net/en/), loss of food can be considerable, counteracting any effort of improving crop productivity (Hodges et al. 2014). Data from over 30 African countries stated that dry weight losses of maize averaged $18 \%$ in 2018. The main reasons for losses were unsuitable storage facilities favoring pests such as the large grain borer (Prostephanus truncatus), which can damage important staple crops such as maize in East Africa (Farrell and Schulten 2002). Future strategies need to focus on both large-scale professional storage and small-scale solutions using, e.g., metal clips with reduced oxygen content (Tefera et al. 2011), new technologies (better grain driers, shellers, stores, etc.), and adopting new marketing arrangements such as collective marketing (Hodges et al. 2013). More sophisticated but paradigmatic for organic farming are various systems of crop diversification.

\section{Agroforesty and polyculture}

In some regions of Africa, the optimal use of natural resources could be achieved by sophisticated systems of agroforestry or polyculture. These systems can be very productive and are well adapted to climatic hazards. The implementation of fertilizer tree systems in Southern Africa, for example, turned out to be an inexpensive technology that significantly raised crop yields and reduced food insecurity, while providing environmental services (Ajayi et al. 2011). Agroforestry systems in SSA can provide pathways for increased food security for poor farmers, while contributing to climate change mitigation (Mbow et al. 2014). However, developing and establishing productive systems, is knowledge intensive, time consuming, and requires investments. Whether or not farmers would finally adopt innovative agroforestry systems remains open.

\section{Nourishing, not only feeding the people}

According to a recent study, calorie supply per capita in Ethiopia has increased during the last decade, while food diversity has decreased, resulting in hidden hunger and malnutrition (Baye et al. 2019). Therefore, a diversification of crop production including more vegetables and fruits, but also more dairy products, has to be targeted in future African agriculture. Again, only increased purchasing power of the African consumer can boost this development.

To satisfy future food demand in Africa, another classical approach needs to be reconsidered as well.

\section{Extending arable land size}

According to the FAO, there are still considerable land reserves in Africa for conversion to arable land, particularly for East and Southern Africa, spanning from the Lake Tana basin in Ethiopia to the Limpopo River basin in South Africa (Finlayson et al. 2018). A recent reassessment of the potential crop area in Africa has shown a wide range of 80 to $247 \times 10^{6}$ ha, when not considering forest conversion (Chamberlin et al. 2014). Important criteria causing variation included the suitability and profitability of cropland conversion as well as the status of land use prior to conversion. Suitable agricultural cropland without forest amounted 247 million ha, but 
only 80 million, if current profitability was factored in. One would argue that economic constraints hinder cropland expansion by smallholder farmers, but the ace remains on the agriculture policies in many SSA countries. Most of these governments facilitate investor access to sizeable areas of land, while smallholder land ownership continues to strive mainly on vulnerable customary rights and rural livelihoods (German et al. 2013). More than 20 million hectares of land have already been transferred to large-scale foreign investments, with ambivalent social implications. In contrast, smallholder cropland expansion in most of these countries is more limited than usually perceived (Chamberlin et al. 2014).

\section{Outlook}

Many of the approaches mentioned here are not new but have already been discussed for more than a decade (Tilman et al. 2002; Foley et al. 2011; van Ittersum et al. 2016). From an agronomic point of view, the para-organic approach seems reasonable for the conditions in SSA. The implementation, however, needs to be predominantly pursued by the countries concerned. A promising future for African agriculture will mainly depend on the overall economic development, in particular with respect to infrastructure and purchasing power of the people. Political and societal changes targeted on public welfare, systematic capacity building, and on strengthening the willingness to perform of the people can help to boost the development. Implementing paraorganic components in agriculture could be an alternative to feed the growing African population in a sustainable way.

Funding Open Access funding enabled and organized by Projekt DEAL.

Open Access This article is licensed under a Creative Commons Attribution 4.0 International License, which permits use, sharing, adaptation, distribution and reproduction in any medium or format, as long as you give appropriate credit to the original author(s) and the source, provide a link to the Creative Commons licence, and indicate if changes were made. The images or other third party material in this article are included in the article's Creative Commons licence, unless indicated otherwise in a credit line to the material. If material is not included in the article's Creative Commons licence and your intended use is not permitted by statutory regulation or exceeds the permitted use, you will need to obtain permission directly from the copyright holder. To view a copy of this licence, visit http://creativecommons.org/licenses/by/4.0/.

\section{References}

Adamtey N, Musyoka MW, Zundel C, Cobo JG, Karanja E, Fiaboe KK, Muriuki A, Mucheru-Muna M, Vanlauwe B, Berset E (2016) Productivity, profitability and partial nutrient balance in maize-based conventional and organic farming systems in Kenya. Agric Ecosyst Environ 235:61-79

Ajayi OC, Place F, Akinnifesi FK, Sileshi GW (2011) Agricultural success from Africa: the case of fertilizer tree systems in southern Africa (Malawi, Tanzania, Mozambique, Zambia and Zimbabwe). Int J Agric Sustain 9(1):129-136

Alibu S, Neuhoff D, Senthilkumar K, Becker M, Köpke U (2019) Potential of cultivating dry season maize along a hydrological gradient of an inland valley in Uganda. Agronomy 2019(9): 606

Baye K, Hirvonen K, Dereje M, Remans R (2019) Energy and nutrient production in Ethiopia, 2011-2015:implications to supporting healthy diets and food systems. PLoS One 14(3): e0213182. https://doi.org/10.1371/journal.pone.0213182

Bhat ZF, Kumar S, Fayaz H (2015) In vitro meat production: challenges and benefits over conventional meat production. Journal of Integrative Agriculture 2015 14(2):241-248

Bjornlund H, van Rooyen A, Stirzaker R (2017) Profitability and productivity barriers and opportunities in small-scale irrigation schemes. International Journal of Water Resources Development 33(5):690-704. https://doi.org/10.1080 /07900627.2016.1263552

Brányiková I, Maršálková B, Doucha J, Brányik T, Bišová K, Zachleder V (2011) Microalgae - novel highly efficient starch producers. Biotechnol Bioeng 108:766-776

Burney, J.A. Naylor, RL, and Postel SL (2013) The case for distributed irrigation as a development priority in subSaharan Africa. PNAS 2013 vol. 110 no. 31 12513-12517

Chamberlin J, Jayne TS, Headey D (2014) Scarcity amidst abundance? Reassessing the potential for cropland expansion in Africa Food Policy 48:51-65

Farrell G, Schulten GGM (2002) Larger grain borer in Africa; a history of efforts to limit its impact. Integr Pest Manag Rev 7: $67-84$

Finlayson CM, Milton GR, Prentice RC, Davidson NC (eds) (2018) The wetland book: II: distribution, description, and conservation. Springer Netherlands, Dordrecht

Foley JA, Ramankutty N, Brauman KA, Cassidy ES, Gerber JS, Mueller ND, O’Connell C, Ray DK, West PC, Balzer C, Carpenter SR, Hill J, Monfreda C, Polasky S, Rockstroem J, Johnston M, Bennett EM, Sheehan J, Siebert S, Tilman D, Zaks DPM (2011) Solutions for a cultivated planet. Nature, Vol 478, 20 October 2011, 337-342

Gadédjisso-Tossou A, Avellán T, Schütze N (2020) Impact of irrigation strategies on maize (Zea mays L.) production in the savannah region of northern Togo (West Africa). Water SA 46(1):141-152. https://doi.org/10.17159/wsa/2020.v46. i1.7894

German L, Schoneveld G, Mwangi E (2013) Contemporary processes of large-scale land acquisition in sub-Saharan Africa: legal deficiency or elite capture of the rule of law? World Dev 48:1-18

Guibert H (1999) Évolution de la matière organique et de la capacité d'échange cationique des alfisols tropicaux cultivés 
Sciences agricoles. Institut National Polytechnique de Lorraine, 1999. Français. NNT: 1999INPL086N

Hodges R, Bennett C, Marc B, Felix R (2013) Tackling postharvest cereal losses in sub-Saharan Africa. Rural21 The International Journal for Rural Development 47:16-18. https://doi.org/10.1016/j.cattod.2016.05.008

Hodges R, Bernard M, Rembold F (2014) APHLIS - Postharvest cereal losses in sub-Saharan Africa, their estimation, assessment and reduction. European Commission, Technical Report, January 2014, https://doi.org/10.2788/19582, online available: ht t p s: / / w w w researchgate. net/publication/274634345_APHLIS_-_Postharvest_cereal_ losses_in_Sub-Saharan_Africa_their_estimation assessment_and_reduction/citation/download, URL accessed 1. May 2020

IAASTD (2009) Global report 2009: International Assessment of Agricultural Knowledge, Science and Technology for Development (IAASTD): global report / edited by Beverly D McIntyre . . [et al.].. ISBN 978-1-59726-538-6

Kassie M, Teklewold H, Jaleta M, Marenya P, Erenstein O (2015) Understanding the adoption of a portfolio of sustainable intensification practices in eastern and southern Africa. Land Use Policy 42:400-411

Kwesiga K, Grotelüschen, Neuhoff D, Senthilkumar K, Döring T, Becker M (2019) Site and management effects on grain yield and yield variability of rainfed lowland rice in the Kilombero floodplain of Tanzania. Agronomy 9(10):632. https://doi. org/10.3390/agronomy9100632

Kwesiga K, Grotelüschen ND, Senthilkumar K, Döring T, Becker M (2020) Effect of organic amendments on the productivity of rainfed lowland rice in the Kilombero floodplain of Tanzania. Agronomy 10(9):1280. https://doi.org/10.3390 /agronomy 10091280

Mäder P, Fliessbach A, Dubois D, Gunst L, Fried P, Niggli U (2002) Soil fertility and biodiversity in organic farming. Science 296:1694-1697

Mbow C, Smith P, Skole D, Duguma L, Bustamante M (2014) Achieving mitigation and adaptation to climate change through sustainable agroforestry practices in Africa. Curr Opin Environ Sustain 2014(6):8-14

Mutiro J, Lautze J (2015) Irrigation in southern Africa: success or failure? Irrigation and Drainage 64(2):180-192. https://doi. org/10.1002/ird.1892
Orzechowski A (2015) Artificial meat? Feasible approach based on the experience from cell culture studies. J Integr Agric 14: 217-221

Rahmann G, Grimm D, Kuenz A, Hessel E (2019) Combining land-based organic and landless food production: a concept for a circular and sustainable food chain in Africa in 2100. Organic Agriculture:1-13

Sanchez PA (2002) Soil fertility and hunger in Africa. Science 295:2019-2020

Shipman MA, Symes MD (2017) Recent progress towards the electrosynthesis of ammonia from sustainable resources. Catalysis Today 286:57-68

Tefera T, Kanampiu F, de Groote H, Hellin J, Mugo S, Kimenju S, Beyene Y, Boddupalli PM, Shiferaw B, Banziger M (2011) The metal silo: an effective grain storage technology for reducing post-harvest insect and pathogen losses in maize while improving smallholder farmers' food security in developing countries. Crop Prot 30:240-245

Tilman D, Cassman KG, Matson PA, Naylor R, Polasky S (2002) Agricultural sustainability and intensive production practices. Nature 418:671-677

Tittonell P, Giller KE (2013) When yield gaps are poverty traps: the paradigm of ecological intensification in African smallholder agriculture. FCR 143:76-90

Tittonell P, Leffelaar PA, Vanlauwe B, van Wijk MT, Giller KE (2006) Exploring diversity of crop and soil management within smallholder African farms: a dynamic model for simulation of $\mathrm{N}$ balances and use efficiencies at field scale. Agric Syst 91(1-2):71-101

van Ittersum MK, van Bussel LGJ, Wolf J, Grassini P, van Wart J, Guilpart N, Claessens L, de Groot H, Wiebe K, MasonD'Croz D, Yang H, Boogaard H, van Oort PAJ, van Loon MP, Saito K, Adimo O, Adjei-Nsiah S, Agali A, Bala A, Chikowo R, Kaizzi K, Kouressy M, Makoi JHJR, Ouattara K, Tesfaye K, Cassman KG (2016) Can sub-Saharan Africa feed itself? Proc Natl Acad Sci U S A 113(52):14,964-14, 969. https://doi.org/10.1073/pnas.1610359113

Publisher's note Springer Nature remains neutral with regard to jurisdictional claims in published maps and institutional affiliations. 